\title{
KAJIAN POTENSI EKONOMI MASYARAKAT NELAYAN DI KABUPATEN KEP. SITARO (STUDI KASUS SIAU BARAT)
}

\author{
Vecky A.J.Masinambow, Jacline I.Sumual, Krest D.Tolosang \\ Ekonomi Pembangunan-Fakultas Ekonomi dan Bisnis \\ Universitas Sam Ratulangi \\ Email :sumualjacline@gmail.com
}

\begin{abstract}
ABSTRAK
Tujuan yang akan di capai dalam penelitian ini adalah untuk mengetahui potensi Ekonomi Masyarakat Nelayan yang ada di wilayah Kabupaten Kepulauan Siau Barat,Mengkaji kaitan antara potensi dan masalah sehingga dapat disusun strategi pengembangan kehidupan perekonomian masyarakat nelayan di Kabupaten Kepulauan Sitaro (Studi Kasus Siau Barat). Manfaat Penelitian Sebagai input atau bahan masukan dan pertimbangan bagi pemerintah Kabupatan Kepulauan Sitaro dalam perencanaan pembangunan wilayah terutama pembangunan ekonomi bagi masyarakat di kawasan pesisir Yakni Masyarakat Nelayan. Hasil penelitian ini berupa Publikasi Artikel Ilmiah dalam Jurnal Terakreditasi yang dapat dijadikan sebagai sumber publikasi bagi Pemerintah Kabupaten Kepulauan Sitaro atau bagi SKPD yang memiliki kaitan dengan pengembangan ekonomi kawasan pesisir di Kabupaten Kepulauan Sitaro.
\end{abstract}

Kata Kunci : Potensi Ekonomi, Nelayan

ABSTRACT

Goals to be achieved in this research is to investigate the potential for Community Economic Fishermen in the region of the Islands District Siau West, Examining the link between the potential and the problems that can be prepared the development strategy of the economic life of fishing communities in the Islands District Sitaro (Case Study Siau West). Benefit Research As an input or input and consideration for the government Kabupatan Sitaro Islands in the planning of regional development, especially economic development for the coastal Namely Fishermen Society. The results of this study are in the Journal of Scientific Publication accredited to serve as a source for the publication of the Government of the Islands District Sitaro or for SKPD, which has links with the economic development of the coastal area in Islands District Sitaro.

Keywords : Economic Potential, Fisherman 


\section{PENDAHULUAN}

Potensi kelautan yang dimiliki oleh Kabupaten Kepulauan Sitaro tahun 2014 adalah sebanyak 16.066,59 ton yang terdiri atas produksi tangkapan ikan sebanyak 16.019 ton dan binatang berkulit lunak sebanyak 47,44 ton. Jenis ikan yang paling besar produksi tangkapannya adalah ikan cakalang dengan jumlah produksi tangkapan tahun 2014 sebesar 3.389,14 ton. Jenis ikan yang lain yang juga memiliki produksi tangkapan yang besar adalah ikan tongkol komo dengan jumlah produksi sebesar $2.734,60$ ton. Ikan layang juga memiliki produksi tangkapan yang cukup besar yakni sebanyak $2.149,48$ ton. Jenis ikan yang lain juga memiliki potensi yang baik diantaranya adalah ikan madidihang,ikan kembung, ikan selar,ikan terbang, ikan tembang dan berbagai jenis yang lain (Sumber : Dinas Kelautan dan Perikanan Kab. Sitaro, 2015).

Potensi sumber daya alam yang dimiliki oleh suatu wilayah sangat berpengaruh dalam konteks perencanaan pembangunan wilayah dimana pendekatan pembangunan yang dipakai didasarkan pada pendekatan perencanaan secara fisik yakni bagaimana pembangunan itu direncanakana dan dilaksanakan melalui pengalokasian faktor-faktor produksi dan hasil produksi sehingga mampu memkasimalkan pekerjaan,pendapatan, dan kesejahteraan masyarakat.(Widodo, 2006).

Dalam konteks perencanaan pembangunan diwilayah Kabupaten Kepulauan Sitaro, potensi sumber daya alam merupakan sumber daya yang harus diperhitungkan dan dimaksimalkan, sebab tulang punggung perekonomian Kabupaten Sitaro banyak ditopang oleh potensi sumber daya alam yang ada.Terlebih potensi yang ada di laut berupa ikan dan hasil laut lainnya yang diharapkan mampu meningkatkan kehidupan perekonomian masyarakat. Pemerintah Kabupaten Kepulauan Sitaro juga sangat peduli dengan potensi bahari sehingga mencatumkan konsep "Blue Economic" dalam Visi dan Misi dalm RPJMD 2014-2019 yang dibingkai dalam "Green Economic".

Kondisi riil yang ada di lapangan dimana masyarakat yang hidup di kawasan pesisir di wilayah Kepulauan Sitaro saat ini justru belum mampu hidup sejahtera melalui keberadaan potensi bahari yang sangat mumpuni. Hal ini mengandung realita paradoks dalam konsep pembangunan wilayah. Melalui kenyataan yang ada, sangat mendesak untuk menelusuri permasalahan yang dihadapi oleh masyarakat nelayan dan masyarakat petani serta elemen masyarakat lainnya yang menggantungkan hidupnya pada hasil laut dan perairan yang ada di Kabupaten Sitaro. Penting untuk dikaji mengenai masalah, harapan, dan kerinduan masyarakat di kawasan pesisir agar dapat diketahui strategi dan kebijakan pembangunan apa yang pas bagi pengembangan kawasan pesisir sehingga pada akhirnya kehidupan perekonomian mereka dapat meningkat di masa-masa yang akan datang. Perlu kajian bagaimana menjembatani problem yang ada ditingkat nelayan dengan program kerja pemerintah daerah sehingga dapat terjadi sinkronisasi pembangunan kawasan pesisir dengan tidak mengesampingkan peran pihak swasta. Hali inilah yang menjadi dasar dari kajian ini.

\section{Kawasan Pesisir}

Kawasan atau wilayah pesisir merupakan pertemuan antara darat dan laut dimana wilayah pesisir meliputi bagian darat baik yang kering maupun yang terendam air, yang masih dipengaruhi oleh sifat-sifat laut seperti pasang surut,angin laut, dan perembesan air asin. Bagian laut wilayah pesisir mencakup bagian laut yang masih dipengaruhi oleh proses-proses alami yang terjadi di darat seperti sedimentasi dan aliran air tawar maupun yang disebabkan oleh kegiatan manusia di darat seperti penggundulan hutan dan pencemaran (Bengen : 2002).

Sumberdaya di wilayah pesisir terdiri atas sumberdaya alam yang dapat pulih dan sumberdaya alam yang tidak dapat pulih.Sumberdaya yang dapat pulih meliputi sumberdaya 
perikanan seperti ikan,moluska,krustasea,plankton,benthos,mamalia laut, rumput laut,padang lamun, hutan mangrove, dan terumbu karang. Sedangkan sumberdaya yang tidak dapat pulih antara lain minyak dan gas bumi,bijih besi,timah,bauksit,mineral serta barang tambang lainnya (Dahuri : 2004).

Sumberdaya pesisir dan perikana kelautan pada hakekatnya memiliki sifat terbaharukan (renewable) melalui mekanisme siklus alamiah.Namun demikian pada tingkat konsumsi yang melebihi kecepatan proses siklus alamiah akan mengalami kelangkaan

\section{Masyarakat Pesisir}

Masyarakat Pesisir (coastal community) diterjemahkan dengan ciri-ciri utama tidak memproduksi barang ataupun jasa tertentu, mengandalkan penghidupan dari sumber daya laut, dan jika ada alat produksi biasanya berupa perahu, dengan sistem ekonomi yang hierarkis seperti ada juragan kapal, tengkulak, buruh, dan nelayan tradisional. Kekayaan pesisir dan kelautan tidak terbatas pada ikan, melainkan hingga meliputi budidaya, kerajinan, pariwisata, energi gelombang, energi angin, energi surya, minyak dan gas serta berbagai potensi lainnya.

\section{METODE PENELITIAN}

\section{Data dan Sumber Data}

Data yang digunakan dalam penelitian ini terdiri atas data primer dan data sekunder. Data primer diperoleh langsung dari lapangan dan bersumber dari para responden maupun sumber informasi kunci (key informan) yang sangat kompeten dengan penelitian ini. Data sekunder diperoleh dari SKPD atau instansi pemerintah di kabupaten Sitaro yang berkaitan dengan topik penelitian ini, seperti Bappeda,Dinas Kelautan dan Perikanan, Dinas Pertanian, Dinas perindustrian dan Perdagangan dan yang lainnya.

\section{Metode Pengumpulan Data}

Metode pengumpulan data yang dipakai dalam penelitian ini adalah metode penelitian lapangan (field research) dan metode kepustakaan (library research).

\section{Variabel-Variabel Penelitian}

Variabel yang digunakan dalam penelitian ini antara lain antara lain :
a. PDRB Kabupaten Sitaro baik ADHB maupun ADHK
b. Pendapatan Masyarakat nelayan maupun Petani
c. Jenis alat tangkap yang digunakan nelayan
d. Harga Ikan
e. Biaya Melaut
f. Harga Komoditi perkebunan
g. Sarana dan infrastruktur pariwisata
h. Jumlah hasil laut seperti ikan, dan hasil laut lainnya.

\section{Metode Penentuan Sampel}

Metode pengambilan sampel dalam penelitian ini menggunakan metode pengambilan secara random sampling dan purposive sampling. Dimana responden yang menjadi sample di bagi sesuai kluster berdasarkan daerah yakni Siau barat. 


\section{Metode Analisis Data}

Analisis data yang digunakan dalam penelitian ini adalah :

- Metode analisis kualitatif yakni mengkaji semua masalah yang ditemui di lapangan dan diuraikan secara kualitatif dan di sajikan dalam bentuk tabel.

- Penelitian ini juga menggunakan analisis dengan pendekatan SWOT (Strenght, Weaknesses, Opportunities, dan Threats) yang bertujuan untuk mengkaji Kekuatan, Kelemahan, Peluang, dan Ancaman dari semua potensi yang ada pada kawasan pesisir di Kabupaten Kepulauan Sitaro (Studi kasus Siau Barat)

- Analisis Klassen Tipologi yang bertujuan untuk mengetahui Potensi Sub Sektor Perikanan dan potensi Sub Sektor Perkebunan dalam perekonomian Kabupaten Kepulauan Siau Tagulandadng Biaro.

\section{HASIL PENELITIAN DAN PEMBAHASAN}

\section{Potensi Sub Sektor Perikanan di Kabupaten Kepulauan Sitaro}

Untuk menganalisis potensi sub sektor perikanan di Kabupaten Kepulauan Siau, Tagulandang, Biaro maka alat analisis yang dipakai adalah Klassen Tipologi. Hasil analisis adalah sebagai berikut :

Tabel 1 Potensi Sub Sektor Perikanan di Kabupaten Kepl.Sitaro Tahun 2009-2014 (Rata-Rata per Tahun)

\begin{tabular}{|c|c|c|c|c|}
\hline $\begin{array}{c}\text { Kontribusi } \\
\text { terhadap } \\
\text { Perekonomian } \\
\text { Sitaro (\%) } \\
\text {-kst- }\end{array}$ & $\begin{array}{c}\text { Kontribusi } \\
\text { terhadap } \\
\text { perekonomian } \\
\text { Sulut (\%) } \\
\text {-ksu- }\end{array}$ & $\begin{array}{c}\text { Pertumbuhan } \\
\text { dalam } \\
\text { perekonomian } \\
\text { Sitaro (\%) } \\
\text {-gst- }\end{array}$ & $\begin{array}{c}\text { Pertumbuhan } \\
\text { dalam } \\
\text { perekonomian } \\
\text { Sulut (\%) } \\
\text {-gsu- }\end{array}$ & Kondisi \\
\hline 13,48 & 4,19 & 5,79 & 6,73 & $\begin{array}{c}\text { kst }>\mathrm{ksu} \\
\text { gst }<\text { gsu }\end{array}$ \\
\hline
\end{tabular}

Sumber : Hasil olahan Data Sekunder

Berdasarkan hasil kajian dalam Tabel maka dapat simpulkan bahwa sub sektor perikanan memiliki potensi yang sangat baik untuk berkembang atau potensial menjadi sub sektor ekonomi yang maju di masa-masa yang akan datang. Hal ini terlihat dari kontribusi rata-rata per tahun sub sektor perikanan terhadap perekonomian Kabupaten Sitaro sebesar 13,48 persen sedangkan kontribusi sub sektor perikanan terhadap perekonomian Sulut hanya 4,19 persen per tahun. Namun pertumbuhan rata-rata sub sektor perikanan di Kabupaten Sitaro hanya 5,79 persen per tahun sedangkan pertumbuhan rata-rata sub sektor perikanan Sulut lebih tinggi yakni 6,73 persen per tahun. 


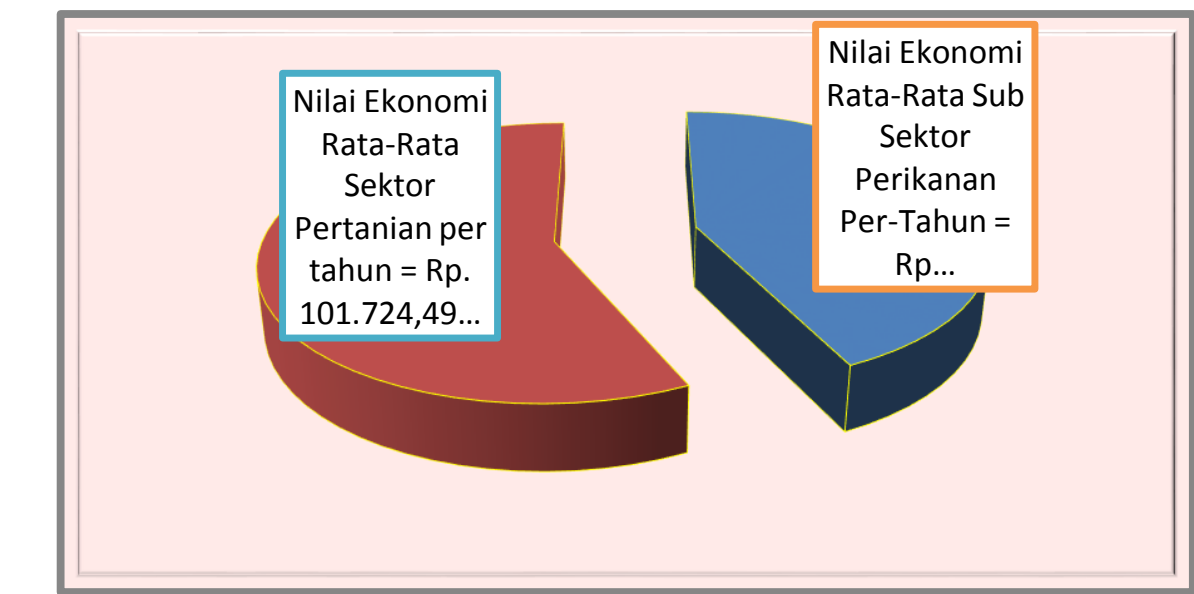

\section{Sumber : Hasil Olahan Data Sekunder \\ Grafik 1 Kontribusi Sub Sektor Perikanan Terhadap Sektor Pertanian di Kabupaten Kepulauan Sitaro}

Hasil kajian yang termuat dalam Grafik diatas menunjukkan bahwa sub sektor perikanan memiliki kontribusi yang besar terhadap nilai perekonomian sektor pertanian di Kabupaten Kepulauan Sitaro. Kontribusi rata-rata sub sektor perikanan terhadap sektor pertanian di Kabupaten Sitaro adalah sebesar 42,93 persen per tahun atau Rp.101.724.490.000 per tahun terhadap nilai perekonomian yang ada dalam sektor pertanian Kabupaten Sitaro.

\section{Masalah Riil yang dihadapi masyarakat Nelayan di Kecamatan Siau Barat}

Untuk mengetahui dan mengkaji masalah riil yang dihadapi oleh masyarakat nelayan yang mendiami kawasan pesisir di Kecamatan Siau Barat maka dilakukan penelitian lapangan (field research) dengan menggunakan kuisioner terhadap para key informan (responden) dari nelayan sebanyak 50 responden yang tersebar di beberapa desa /kelurahan di wilayah kecamatan Siau Barat yang menjadi daerah sampel. Responden yang digunakan adalah responden yang benarbenar dianggap memahami seluk beluk permasalahan yang dihadapi nelayan di Kecamatan Siau Barat. Hasil kajian di lapangan ditemui hal-hal sebagai berikut :

- Tingkat Pendidikan

Tingkat pendidikan merupakan syarat penting bagi seseorang untuk mendapatkan kehidupan yang lebih baik. Adapun Tingkat pendidikan responden adalah sebagai berikut :

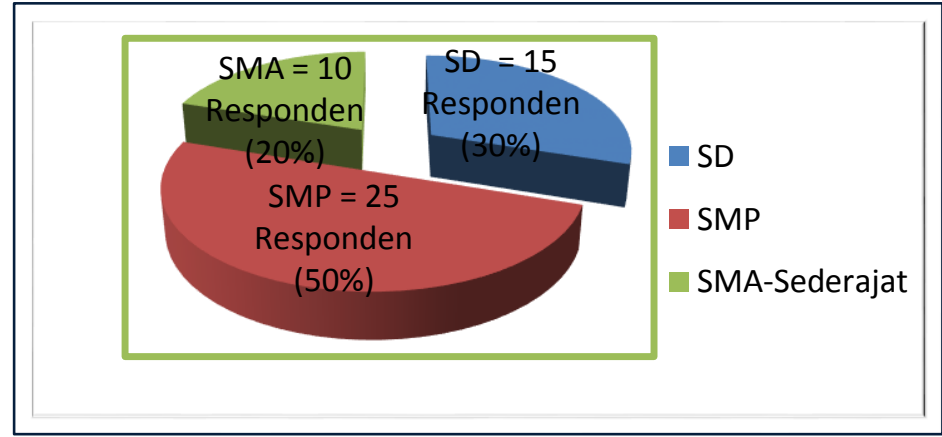

Sumber : Hasil wawancara dan olahan data primer

Grafik 2 Tingkat Pendidikan Responden 
Hasil kajian menunjukkan bahwa repsonden penelitian ini sebagian besar merupakan lulusan SMP yakni 25 orang responden atau $50 \%$ dari total responden. Lulusan SD berjumlah 15 orang atau $30 \%$ dari total responden. Sedangkan lulusan SMA hanya 10 orang atau $20 \%$ dari total responden. Dapat disimpulkan bahwa sebagian besar masyarakat nelayan di Kecamatan Siau Barat pernah mengecap pendidikan hingga SMP.

- Keikutsertaan dalam Pelatihan

- Masalah Riil Nelayan Tangkap Tradisional

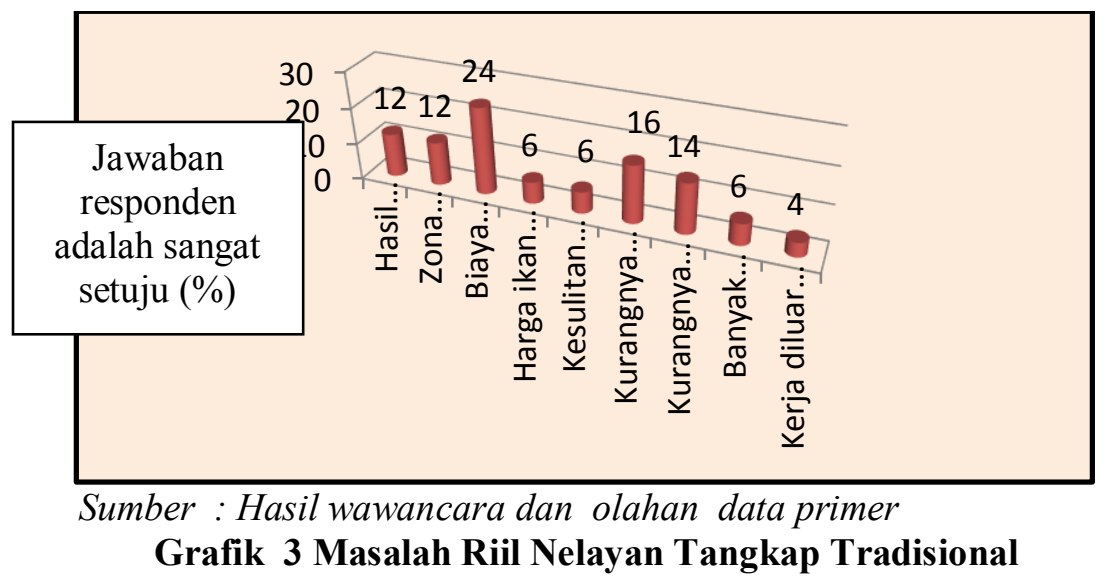

Hasil kajian di lapangan menunjukkan bahwa masalah utama dari nelayan tradisional saat ini adalah biaya melaut yang semakin mahal. Kondisi di daerah penelitian didapati harga bahan bakar bensin untuk melaut per liter adalah Rp.15.000 hingga Rp.20.000. Untuk sekali melaut maka nelayan membutuhkan bensin minimal 2-3 liter. Harga barang lain juga tergolong mahal seperti alat pancing berupa tali dan mata kail, dan jala. Bahan makanan seperti beras dan rempah-rempah yang dipakai sebagai bekal lauk pauk juga mahal. Oleh karena itu $24 \%$ atau 12 orang responden menjawab sangat setuju bahwa biaya melaut semakin mahal. Masalah selanjutnya adalah kurangnya bantuan dari pemerintah daerah terhadap nelayan tradisional. Sebanyak $16 \%$ atau 8 orang responden sangat setuju dengan pilihan ini. Menurut mereka kalaupun ada bantuan itu sering tidak sesuai dengan yang dinginkan oleh para nelayan dan ada kecenderungan pilih kasih dan tidak tepat sasaran. Masalah yang lain adalah kurangnya atau hampir tidak ada lembaga ekonomi seperti koperasi nelayan yang dapat membantu nelayan terutama dalam penyediaan pinjaman modal. Sebanyak $14 \%$ atau 7 orang responden sangat setuju bahwa hal ini merupakan masalah bagi nelayan tradisional. Masalah yang adalah hasil tangkapan ikan yang makin berkurang akibat adanya penguasaan zona tangkap oleh nelayan besar yakni pengusaha pajeko. $12 \%$ responden menjawab sangat setuju dengan masalah ini. Harga ikan yang murah, kesulitan dalam menjual ikan, kurangnya minat masyarakat untuk menjadi nelayan terutama generasi muda akibat pekerjaan diluar nelayan jauh lebih menguntungkan, juga merupakan masalah yang sering dihadapi oleh para nelayan tradisional di kawasan pesisir kabupaten Sitaro secara maupun nelayan di Kecamatan Siau Barat.

- Potensi dan Masalah Pengembangan Wisata Bahari dan Pantai di Kecamatan Siau Barat

Kabupaten Kepulauan Sitaro secara umum memiliki laut dan pantai yang bersih dan indah. Panorama eksotis daerah kepulauan sangat jelas terlihat di wilayah kepulauan Sitaro. Demikian juga di kawasan bahari kecamatan Siau Barat. Wilayah pantai di kecamatan Siau Barat memiliki keindahan alamiah yang belum tersentuh dengan polusi. Potensi pengembangan wisata bahari sangat terbuka lebar sebab kondisi laut yang bersih, alamiah dan bebas dari pencemaran serta pantai dan pulau yang menarik dengan berbagai pemandangannya menjadi peluang destinasi wisata domestik dan internasional.

Sebagai contoh adalah pantai di Desa Lehi dengan mata air panasnya dan memiliki area atau spot menyelam yang indah, pantai di desa Mini sebagai tempat tujuan wisata petualangan 
alam. Selain itu keindahan panorama pantai di Kelurahan Ondong dan Paseng, serta desa Peling dan desa Peling Sawang juga sangat menarik untk di kunjungi dan digunakan sebagai tempat berenang dan olahraga menyelam. Pulau Makalehi di sebelah barat pulau Siau memiliki potensi wisata bahari dan petualangan yang sangat baik. Spot penyelaman yang indah serta adanya danau di tengah pulau dengan pemandangan yang eksotik dari puncak bukit Makalehi menjadikan pulau ini menjadi salah satu destinasi wisata local di Kecamatan Siau Barat.

Namun kondisi yang ada juga tak lepas dari berbagai masalah dan hambatan yang ada di daerah. Hasil kajian mengenai masalah yang dihadapi dalam pengembangan wisata bahari di Kecamatan Siaua Barat adalah sebagai berikut :

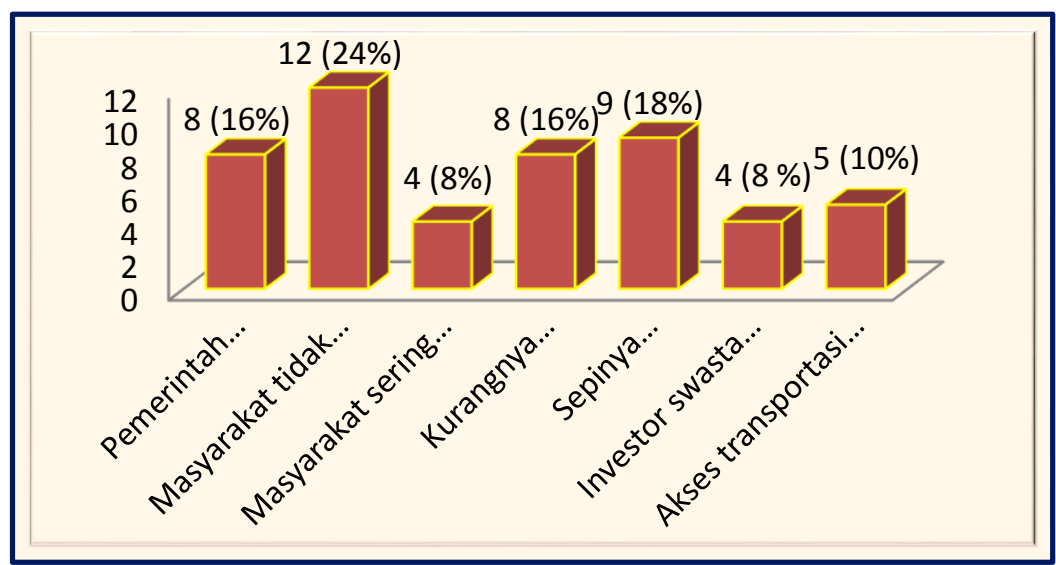

Sumber : Hasil wawancara dan olahan data

\section{Grafik 4 Masalah Pengembangan Wisata Bahari}

Masalah utama yang dihadapi oleh masyarakat dan pemerintah dalam pengembangan wisata bahari di Kabupaten Kepulauan Sitaro berdasarkan kajian di lapangan adalah belum adanya titik temu antara warga sebagai pemilik lahan dan lokasi dimana didalmnya terkandung potensi wisata, sehingga warga tidak mau memberikan ijin lokasi dan lahannya dijadikan sebagai jalan ataupun area wisata. Kondisi yang lain adalah sepinya pengunjung pada tempattempat wisata. Kurangnya peran pemerintah daerah dalam menyiapkan infrstruktur penunjang serta mempromosikan potensi wisata yang ada melalui berbagai media massa maupun internet sehingga masyarakat domestic luar Sitaro dan jugamasyarakat internasional mengetahui dan tertarik untuk datang mengunjungi tempat wisata-wisata yang ada terutama wisata bahari.Akses trnsportasi yang kurang lancar dan mahal menuju tempat wisata indah namun terpencil (seperti ke Pulau Manumpitaeng dan Pulau Mahoro), kurangnya ketertarikan investor untuk menanamkan modal pembangunan sektor wisata bahari, serta kurangnya kesadaran masyarakat untuk menjaga potensi wisata yang ada sehingga cenderung merusak, misalnya penggunaan bom ikan dapat merusak potensi keindahan karang dan terumbunya yan indah.

\section{Analisis SWOT terhadap Potensi Kelautan dan Perikanan Kecamatan Siau Barat Kabupaten Kepulauan Siau Tagulandang Biaro.}

Tujuan analisis SWOT adalah untuk mengetahui Kekuatan (Strength), Kelemahan (Weaknesess), Peluang (Opportunities) dan Ancaman (Threats) dari sumberdaya kelautan dan bahari yang ada di wilayah Kabupaten Kepulauan Siau Tagulandang Biaro secara umum dan Kecamatan Siau Barat secara khusus. Berdasarkan kajian lapangan dengan menggunakan data primer dari para responden (key informan) di wilayah Kecamatan Siau Barat.

a. Kekuatan (Strength)

Adapun kekuatan yang dimiliki oleh sumberdaya kelautan dan perikanan di wilayah ini adalah sebagai berikut : 
- Memiliki wilayah laut yang luas

- Laut yang bersih dan belum tercemar

- Potensi perikanan yang melimpah

- Potensi hasil laut lain yang cukup melimpah

- Terumbu karang yang indah yang dapat dijadikan sebagai spot olahraga menyelam dan snorkling

- Banyak pantai yang indah dan alami dan dapat dijadikan sebagai tujuan wisata bahari.

- Semangat berusaha sebagai nelayan yang sangat tinggi

b. Kelemahan (Weaknesses)

Adapun yang menjadi kelemahan dalam pemberdayaan potensi kelautan dan perikanan adalah sebagai berikut :

- Nelayan tangkap sampai saat ini masih menggunakan alat tangkap yang masih tradisional

- Hasil tangkapan ikan dan hasil laut masih sangat terbatas

- Pendapatan nelayan tangkap tradisional masih tergolong rendah

- Kehidupan nelayan tradisional juga dapat dikategorikan sebagai miskin

- Harga BBM yang tinggi menjadikan biaya produksi untuk melaut tergolong tinggi

- Kurangnya lembaga ekonomi yang diharapkan dapat membantu nelayan dalam masalah modal kerja maupun pemasaran hasil tangkapan.

- Akses nelayan untuk mendapatkan modal dari pihak perbankan sangat sulit

- Kurangnya pendidikan dan pelatihan bagi para nelayan dari pemerintah daerah

- Bantuan yang diberikan pemerintah melalui SKPD terkait seperti Dinas Perikanan dan Kelautan masih sangat kurang dan sering tidak sesuai dengan yang dibutuhkan oleh para nelayan.

c. Peluang (Opportunities)

Peluang-peluang yang dapat dikembangkan dalam potensi yang dimiliki oleh sumberdaya kelautan dan perikanan di wilayah Siau Tagulandang Biaro secara umum dan di Kecamatan Siau Barat pada khususnya adalah sebagai berikut :

- Permintaan ikan yang tinggi baik oleh pasar lokal Sitaro, maupun permintaan dari wilayah lain di sekitar Sitaro merupakan peluang yang baik bagi para nelayan untuk meningkatkan pendapatannya.

- Perencanaan Pembangunan Ekonomi yang dilakukan oleh pemerintah Kabupaten Sitaro saat ini yang mempriotaskan potensi kelautan dan perikanan akan memberikan peluang yang baik bagi nelayan tangkap tradisional di Kecamatan Siau Barat.

d. Ancaman (Threats)

Hal-hal yang dapat muncul menjadi ancaman bagi kelangsungan dan keanekaragaman hayati (biodiversity) bahari dan perikanan di Kabupaten Sitaro secara umum dan di Kecamatan Siau Barat secara khusus adalah sebagai berikut :

- Praktek penangkapan ikan secara terlarang (illegal fishing) yang dilakukan oleh nelayan-nelayan asing di perairan laut Kabupaten Sitaro.

- Adanya intervensi dari nelayan-nelayan daerah lain diluar Sitaro dengan menggunakan teknologi tangkap ikan yang canggih yang beroperasi di wilayah laut Kabupaten Sitaro.

- Penggunaan bom ikan oleh para nelayan sehingga dapat merusak terumbu karang dan membunuh ikan-ikan kecil.

- Penggunaan racun ikan sehingga dapat memetikan pertumbuhan biota laut dan juga ikan serta hewan laut yang lainnya.

- Adanya abrasi pantai yang mengakibatkan rusaknya beberapa pantai sehingga mengurangi keindahan pantai

- Adanya tanggul penahan ombak yang dibangun di bibir pantai sehingga menyulitkan nelayan untuk mendaratkan perahu mereka lebih jauh ke daratan pantai. 


\section{Strategi Meningkatkan Pendapatan Nelayan di Kecamatan Siau Barat}

Potensi perikanan dengan laut yang luas di wilayah Kabupaten Kepulauan Sitaro secara umum dan di Kecamatan Siau Barat secara khusus, semestinya menjadi peluang yang baik bagi masyarakat nelayan di Kecamatan Siau Barat untuk meningkatkan pendapatan dan taraf hidupnya. Berdasarkan hasil kajian di lapangan maka ada beberapa kebijakan atau strategi yang dapat dilakukan, baik oleh nelayan itu sendiri maupun pemerintah Kabupaten Kepulauan Siau Tagulandang Biaro, antara lain sebagai berikut :

- Pemerintah perlu memberikan dan meningkatkan pelatihan kepada para nelayan tentang penagkapan ikan dengan menggunakan teknologi yang modern.

- Pemerintah daerah sebelum memberikan bantuan harus mengecek langsung ke nelayan kebutuhan alat tangkap atau bantuan yang lain yang benar-benar sesuai dengan kebutuhan dan keperluan mereka.

- Aspirasi maupun permohonan bantuan yang diajukan oleh masyarakat nelayan melalui kelompok-kelompok nelayan maupun secara perorangan kepada pemerintah daerah hendaknya dapat ditindaklanjuti sebab kajian dilapangan menunjukkan bahwa sudah sering dilakukan permohonan bantuan kepada pemerintah namun sering terabaikan, ataupun jika mendapatkan bantuan sering tidak sesuai dengan yang diharapkan oleh para nelayan.

\section{Analisis SWOT Terhadap Potensi Perkebunan di Kecamatan Siau Barat Kabupaten Kepulauan Sitaro}

a. Kekuatan (Strength)

Adapun yang menjadi kekuatan bagi sub sektor perkebunan di wilayah kecamatan Siau Barat ialah :

- Memiliki struktur tanah dan iklim yang sangat cocok dan menunjang bertumbuh suburnya perkebunan pala, kopra, cengkih.

- Hasil perkebunan pala merupakan komoditi yang memiliki kualitas terbaik di dunia dan menguasai dua pertiga ekspor komoditi pala dunia.

- Hasil perkebunan kelapa dan cengkih juga memiliki kualitas yang baik.

b. Kelemahan (Weaknesess)

- Harga komoditi pala, kopra, dan cengkih sering fluktuatif sehingga yang paling cepat menerima dampaknya adalah petani.

- Harga komoditi pala, kopra, dan cengkih cenderung diatur dan di monopoli oleh pengusaha besar di Pulau Siau lebih khusus lagi di Ulu dan Ondong.

- Belum ada produk turunan dari komoditi pala, kopra, dan cengkih, yang dapat menembus skala ekspor.

- Cuaca dan iklim yang panas sangat mengganggu produksi dan pertumbuhan komoditi.

c. Peluang (Opportunities)

- Produksi pala telah menjadi komoditi unggulan yang memiliki skala ekspor yang menguasai dua pertiga permintaan pasar dunia.

- Pasar bebas asean (MEA) menjadi pasar yang cukup potensial dan akan menarik investor untuk menanamkan modalnya pada komoditi unggulan Kabupaten Sitaro dalam sub sektor perkebunan.

- Kualitas komoditi yang sangat baik memungkinkan produk turunannya juga akan berkualitas, sehingga sangat potensial dan berpeluang untuk membuat minyak pala, sirop pala, dodol pala, minyak goreng sebab permintaan terhadap produk turunan tersebut sangat terbuka pasarnya nanti di Era MEA 2016.

d. Ancaman (Threats)

- Persaingan di pasar ekspor dari komoditi pala negara Granada (Afrika Timur) makin menyaingi kualitas ekspor pala dari Kabupaten Kepulauan Sitaro 
- Daerah lain di Sulut saat ini gencar melakukan penanaman pala

- Penyakit dan virus pala Sitaro membuat permintaan pasar Eropa berkurang sehingga harganya mengalami penurunan terutama pada level petani.

- Kekeringan dan kemarau panjang saat ini mengancam pertumbuhan dan produksi pala, kelapa dan cengkih

\section{Strategi dan Kebijakan dalam Rangka Meningkatkan Kehidupan Ekonomi Masayarakat Petani di Kecamatan Siau Barat}

- Pemerintah daerah harus memfasilitasi dan mengintervensi sistem perniagaan komoditi pala terutama mengurangi peran monopoli maupun oligopoli yang justru menguasai dan mengatur harga pala di Sitaro sehingga petani tidak selalu menjadi pihak yang dirugikan.

- Pemerintah daerah perlu membuka seluas-luasnya kesempatan untuk berinvestasi bagi pengusaha dari luar daerah maupun luar negeri agar dapat menanamkan modalnya pada pasar komoditi unggulan Kabupaten Sitaro.

- Masyarakat perlu mendapatkan akses yang jelas tentang harga komoditi unggulan di pasar dunia melalui peran internet. Oleh karena itu pemerintah daerah harus mampu memfasilitasi hal tersebut melalui web site pemerintah Sitaro sehingga masyarakat dengan mudah dapat mengetahui harga pasar pala, kopra, dan cengkih di pasar dunia agar mereka memahami berapa margin harga yang seharusnya berlaku di tingkat petani.

- Perlu juga "menjual" potensi produk turunan dari Pala, Kopra, cengkih ke konsumen nasional maupun dunia melalui dunia maya (internet).

- Perlu melakukan peremajaan pala,kelapa, dan cengkih dengan varietas dan bibit yang baik dan unggul.

\section{KESIMPULAN DAN SARAN}

Berdasarkan hasil penelitian dan pembahasan maka dapat disimpulkan beberapa hal sebagai berikut :

- Potensi ekonomi yang ada di wilayah Kecamatan Siau Barat secara umum bertumpu pada sumber daya alam yakni potensi kelautan dan perikanan serta potensi perkebunan yang didominasi oleh perkebunan pala dan kelapa.

- Potensi laut dan perikanan (Blue Economic) yang ada di Kecamatan Siau Barat adalah sangat potensial namun jika dikaitkan dengan tingkat kehidupan masyarakat nelayan yang mendiami wilayah pesisir di Kecamatan Siau Barat keberadaan potensi lautan dan perikanan yang sangat potensial belum memberikan peningkatan kesejahteraan yang signifikan bagi masayarakat nelayan.

- Kondisi keterampilan masyarakat masih bersifat kapasitas tradisional dalam mengelola pasca panen dari hasil perikanan dan hasil laut lainnya serta hasil perkebunan, termasuk dalam kelembagaan dan pemasarannya

- Potensi ekonomi darat (Green Economic) yakni dari hasil perkebunan darat berupa pala dan kelapa menjadi sandaran dari para nelayan jika mereka diperhadapkan dengan situasi alam dan laut yang kurang bersahabat. Selain berprofesi sebagai nelayan maka mereka juga berprofesi sebagi petani. Potensi ekonomi darat lebih dominan dalam peningkatan kesejahteraan masayarakat di kecamatan Siau Barat dari pada potensi bahari dan perikanan. Hal ini menjadi tantangan bagi pemerintah Kabupaten Kepulauan Siau Tagulandang Biaro.

\section{Saran}

- Upaya pemberdayaan masyarakat pesisir memerlukan usaha yang sistematis serta berkelanjutan 
- Upaya pemberdayaan masayarakat pesisir memerlukan target sampai pada pencapaian kemandirian dalam berbagai aspek seperti: dalam menentukan produksi, distribusi, dan pemenuhan konsumsi disertai kemampuan dalam mengakses dan memeberikan aspisasi yang efektif.

- Peran Pemerintah dalam peningkatan kemampuan dan ketrampilan masyarakat nelayan maupun Petani, agar mampu mengelola potensi perikanan dan Perkebunan dengan baik sehingga dapat meningkatkan kesejahteraan masyarakat.

\section{DAFTAR PUSTAKA}

Arsyad,L, 2004, Ekonomi Pembangunan Edisi ke-4, Penerbit STIE Yayasan Keluarga Pahlawan, Yogyakarta

Bengen D,G (2002), Ekosistem dan Sumber Daya Alam Pesisir dan Laut, Penerbit Pusat Kajian Sumber Daya Pesisir, Institut Pertanian Bogor

Boediono (2001); Ekonomi Moneter (Seri synopsis PIE Nomor 5), BPFE, Yogyakarta

Blakely, E.J and Bradshaw T. K, 2002, Planning Local Economic Development : Theory and Practice, Sage Publications Inc. C.A. Thousands Odds.

Dahuri, 2004, Pengelolaan Sumber Daya Wilayah Pesisir dan Lautan Secara Terpadu, Penerbit Pradnya Paramitha Jakarta.

Deliarnov, 1995, Pengantar Ekonomi Makro, Penerbit Universitas Indonesia Press, Jakarta

Jhingan,M.L, 2004, Ekonomi Pembangunan dan Perencanaan, Penerbit PT.RajaGrafindo Persada,Jakarta

Murni Asfia,2006, Ekonomika Makro, Penerbit PT.Refika Aditama Bandung

Musgrave, 1993, Public Finance in The Theory and Pracice, Mc.Graw Hill, Kogakush, Ltd Tokyo

Sukirno,S, 2001, Ekonomi Pembangunan, Proses, Masalah dan Dasar Kebijakan, Lembaga Penerbit FEUI Jakarta

Suparmoko, I, 2002, Ekonomika Pembangunan, Lembaga Penerbit FE UGM

Yogyakarta.

Suryana (2005), Mikro Ekonomi, Penerbit Erlangga. Jakarta.

Sukirno,S, 2006, Makroekonomi Teori Pengantar, Edisi Ketiga, Penerbit Rajawali Pers, Jakarta

Todaro, P. Michael, (2004), Pembangunan Ekonomi di Dunia Ketiga, Penerbit Erlangga

Jakarta

Tarigan,R, 2005, Ekonomi Regional Teori dan Aplikasi, Edisi Revisi, Penerbit

Bumi Aksara Jakarta

Tambunan, Tulus T.H (2009); Perekonomian Indonesia, Penerbit Ghalia Indonesia, Jakarta.

Todaro, Michael P and Stephen C. Smith (2003); Economic Development diterjemahkan menjadi Pembangunan Ekonomi di Dunia Ketiga Alih Bahasa Haris Munandar dan Puji A.L. 2004. Penerbit Erlangga, Jakarta. 
